\section{Frost Hardiness of Asparagus officinalis L.}

\author{
Rajeev Arora and Michael E. Wisniewski \\ U.S. Department of Agriculture, Agricultural Research Service, \\ Appalachian Fruit Research Station, 45 Wiltshire Road, Kearneysville, \\ WV 25430
}

\section{Donald J. Makus \\ U.S. Department of Agriculture, Agricultural Research Service, Booneville, AR 72927}

\section{Additional index words. $\mathrm{L} \mathrm{T}_{50}$, ion leakage, ice nucleation}

\begin{abstract}
Frost damage to 'Jersey Giant' asparagus (Asparagus officinalis L.) spears was evaluated in noncovered and black plastic-covered field plots following a spring frost episode. In the noncovered plots, $78 \%$ of spears were killed as compared to only $17 \%$ under the plastic rowcovers. Laboratory studies using natural frost simulations indicated that the spears of both treatments were frost hardy to - 2.8C. Air temperature data in the field plots during the frost episode indicated that spears in noncovered plots were at lower temperatures $(-4.0$ to $-4.8 \mathrm{C}$ vs. $-2.8 \mathrm{C}) \approx 4$ to 5 hours longer than spears under rowcovers. The large difference in the spear-kill may be due to the difference in the combined effect of the degree and duration of freezing to which the spears had been exposed.
\end{abstract}

Asparagus can experience an occasional spring frost, causing substantial loss of marketable yield. Studies have been conducted to determine the effect of different types of rowcovers on the yield and quality (total soluble solids, ascorbic acid and phenol content, $\mathrm{pH}$, etc.) of asparagus, and significant differences were noted between covered and noncovered plots (Makus and Gonzalez, 1991). During these studies, $100 \%$ spear-kill was observed in treatments that were not covered as compared to $50 \%$ in those covered by black plastic. Air temperature close to spears, however, dropped below $-3 \mathrm{C}$ in both treatments. Although studies have been reported on the freeze damage in asparagus crowns (Valenzuela and Bienz, 1989) and the frost hardiness of asparagus seedlings (Burrows et al., 1989), to our knowledge, no data are available on the frost hardiness of asparagus spears. The present study was undertaken to 1) assess the frost hardiness of asparagus spears and 2) study the effect of plastic rowcovers on the survival of asparagus spears following a frost episode.

Received for publication 22 Oct. 1991. Accepted for publication $18 \mathrm{Feb}$. 1992. The cost of publishing this paper was defrayed in part by the payment of page charges. Under postal regulations, this paper therefore must be hereby marked $a d$ vertisement solely to indicate this fact.
The production site consisted of an Enders stoney silt loam that had been planted in Apr. 1986 to 'Jersey Giant' seedlings. The 7.3-m plots (rows) were covered on 8 Mar. 1991 using nylon reinforced 0.1 -mm-thick black plastic (Griffolyn, Reef Industries, Houston) supported by metal hoops ( $2 \mathrm{~m}$ apart) 0.35 $\mathrm{m}$ above the soil surface (Makus and Gonzalez, 1991). Noncovered rows were used as a control treatment. Beginning 20 Mar. spears $\geq 15 \mathrm{~cm}$ long were cut at 2- or 3-day intervals. Measurements of mean hourly air tem-

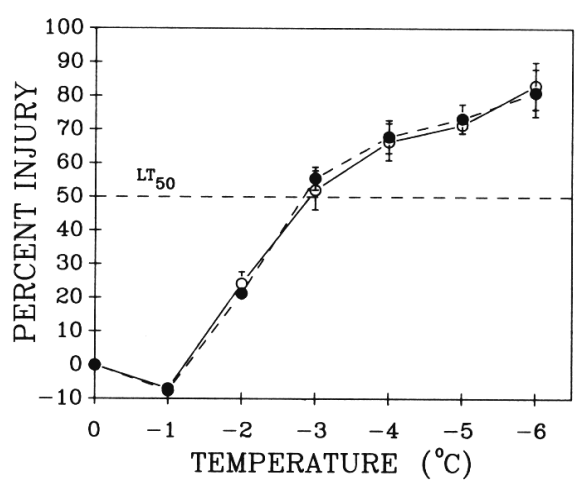

Fig. 1. Frost hardiness, expressed as $\mathrm{LT}_{50}$, of 'Jersey Giant' asparagus spears grown under black plastic cover ( $\bullet-.-\cdot)$ or no cover control $(\mathrm{O}-\mathrm{O})$ in the field. Each point, mean of four replications: bar, $\pm \mathrm{SE}$. peratures during a nocturnal frost on 31 Mar. were collected with a CR-10 data logger (Campbell Sci, Logan, Utah) connected to two Vaisala temperature probes (thermistor); these were placed $15 \mathrm{~cm}$ above the soil surface in one replicate each in the covered and noncovered field plots. Tissue temperatures were not measured. Frost damage was visually assessed $24 \mathrm{~h}$ later. Spears that were watersoaked, shrivelled, and had lost turgidity were counted as dead. Percent spear-kill was then calculated by [dead/(dead + alive $)]$ $\times 100$. The arcsin of the square root of the percent spear kill was weighted for the number of spears/treatment/replication. Statistical differences were determined by analysis of variance. Both treatments were replicated in four randomized complete blocks.

For frost hardiness evaluation, healthy spears were harvested from covered and noncovered plots on 8 Apr., kept cold in insulated containers, shipped to Kearneysville, W.Va., and processed within $24 \mathrm{~h}$ of harvest. These spears were at the same stage of development as those that were examined for frost injury in the field. Frost hardiness of uniformly sized and shaped spears $(\approx 10$ to $12 \mathrm{~g} / \mathrm{spear}$ and $15 \mathrm{~cm}$ long) was assessed by the method of Sukumaran and Weiser (1972). Briefly, $1.0 \pm 0.1 \mathrm{~g}$ stalk $(5 \mathrm{~cm}$ below apex) was transferred into $16 \times 150$ $\mathrm{mm}$ test tubes and cooled in a refrigerated ethylene glycol bath (Neslab Instruments, Newington, N.H.). Tissues were nucleated at $-0.5 \mathrm{C}$ and further cooled at the rate of $1 \mathrm{C} / 30 \mathrm{~min}$ to treatment temperatures. Samples were held at the treatment temperature for $30 \mathrm{~min}$, removed, and thawed overnight on ice. Unfrozen tissue kept on ice served as a control. Ion leakage from thawed tissues

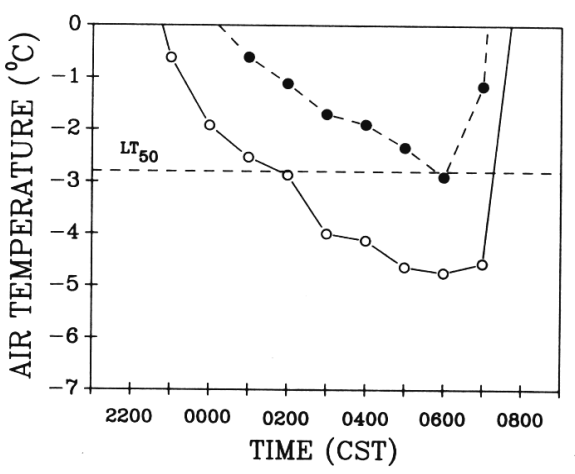

Fig. 2. Air temperatures (in the subfreezing range) recorded during a spring frost in the asparagus plots. Spears were either under plastic cover $(\bullet-.-\bullet)$ or no cover $(0-0)$. Data were collected at 60 -sec intervals and reported as hourly means. 
was measured using the conductivity method (Arora and Palta, 1988). Ion leakage data (expressed as percentage of total) were then used to determine percent injury using the formula employed by Zhang and Willison (1986). Frost hardiness $\left(\mathrm{LT}_{50}\right)$ was defined as the temperature at which $50 \%$ injury occurred. Ion leakage measurements included four replicates/rowcover treatment/temperature.

Field observations indicated a $78 \%$ spearkill in the noncovered plots, following a frost episode, as compared to only $17 \%$ in those plots that were covered with black plastic (differences statistically significant at $P \leq$ $0.05)$. No difference in frost hardiness was detected between spears obtained from the covered and noncovered treatments as indicated by the data from experimental frost simulations in the laboratory (Fig. 1). Spears collected from both cultural management systems exhibited an $\mathrm{LT}_{50}$ of about $-2.8 \mathrm{C}$. Similar results were obtained with the spears from subsequent harvests (data not shown). These results are also in accordance with preliminary data obtained the previous year. Although Burrows et al. (1989) reported the $\mathrm{LT}_{50}$ of asparagus seedlings to be between -2.5 and $-4.5 \mathrm{C}$, this is the first report, to our knowledge, on the evaluation of frost hardiness of asparagus spears.

Our results indicate that the differential sensitivity of spears to frost in the covered and noncovered field plots was not due to inherent differences in their frost hardiness. Our experimental data (Fig. 1) along with air temperature data (Fig. 2) indicate, however, that spears in noncovered plots experienced temperatures lower than $-2.8 \mathrm{C}$ (frost hardiness) for $\approx 4$ to $5 \mathrm{~h}$ longer than spears under plastic. Similar temperature and percent spear-kill data was obtained during a frost episode in a previous year (data not shown). Moreover, it appears that noncovered spears experienced air temperatures at least $2 \mathrm{C}$ lower than the covered spears (Fig. 2). Assuming that the tissue temperatures were relatively close to air temperature, the magnitude of the freezing stress (a combined effect of degree and duration of freezing) experienced by noncovered spears was much greater than the covered spears. Steffen and Palta (1987) have demonstrated that the duration of freezing is a critical component of ultimate frost survivability of plant species, particularly at the critical temperatures. Our results would support this view and may, in part, help explain the differences in spearkill in the covered and noncovered plots despite the similarity in inherent frost hardiness of the spears. A relatively low amount of injury observed in covered spears, however, could also be due to the ability of these tissues to recover from moderate stress during the post-thaw period (Arora and Palta, 1988). Also, differences in the spear-kill in the covered and noncovered plots may occur due to differences in the extent and the temperature of ice nucleation (unpublished results).

\section{Literature Cited}

Arora, R and J.P. Palta. 1988. In vivo perturbation of membrane-associated calcium by freeze-thaw stress in onion bulb cells. Plant Physiol. 87:622628.

Burrows, R.L., L. Waters, Jr., and A.H. Markhart, III. 1989. Cold acclimation of asparagus seedlings subjected to low temperatures or water stress. HortScience 24(5):812-814.

Makus, D.J. and A.R. Gonzalez. 1991. Production and quality of white asparagus grown under opaque rowcovers. HortScience 26(4):374-376.

Steffen, K.L. and J.P. Palta. 1987. Photosynthesis as a key process in plant response to low temperature: Alteration during low temperature acclimation and impairment during incipient freeze-thaw injury, p. 67-99. In: P.H. Li (ed.). Plant cold hardiness. Alan R. Liss, New York.

Sukumaran, N.P. and C.J. Weiser. 1972. Freezing injury in potato leaves. Plant Physiol. 50:564567.

Valenzuela, H.R. and D.R. Bienz. 1989. Asparagus aphid feeding and freezing damage asparagus plants. J. Amer. Soc. Hort. Sci. 114:578581.

Zhang, M.I.N. and J.H.M. Willison. 1986. An improved method for the measurement of frost hardiness. Can. J. Bot. 65:710-715. 